\title{
Out of Time, or Anderson's National Temporality Revisited
}

TORGEIR E. FJELD, University of Gdansk, Poland

\begin{abstract}
In his influential study Imagined Communities, Benedict Anderson makes the claim that a novel conception of time is inaugurated by the introduction of nations: in contrast to the agrarian sense of time as cyclical and characterised by recurrence, the time of the nation is linear, homogeneous and empty. This notion of temporality is drawn from an earlier work by Walter Benjamin, who posits the linearity of traditional historiography with what he refers to as Messianic time, which is to be understood as a temporality where the moment of redemption is an ever-present potentiality. This essay sets out to delineate these three notions of time, and then goes on to discuss this third temporality in greater detail. First, it can be considered as a psychological time, or a mind time, that governed by traumatic encounters. This sense is shown as a strictly logical time in the work of Jacques Lacan. Second, it is a time of grace, in the sense that it is governed by necessity. Blaise Pascal and the Jansenists went to great length to refute the dominant notion of grace as sufficient. If there is an instance that determines events, then the means by which this instance governs can only be a necessary cause. Finally, the work of Benedict Anderson, and particularly a later article in his corpus, is reconsidered. Here, Anderson argues that the effects of globalization have to some extent rendered the temporal linearity of nationalism obsolete. It is therefore apt to consider what a time after nationalism will be like.
\end{abstract}

\section{KEYWORDS}

Benedict Anderson; Walter Benjamin; Martin Heidegger; Nationalism; Psychoanalysis; Temporality 
Consider for a moment this parable:

There's a strong wind blowing from the future -- a place very different from and much better than this. Whenever we in the present see pain and misery this storm pulls us away. This wind of the future bars our ability to alleviate suffering in the present. ${ }^{1}$

It brings to the fore three sense of being out of time.

Out of time: from a time different from our own, a force makes itself felt -- a storm that comes out of a future which hinders our potentiality for compassion in the present. In this sense it is as if something emerges from the domain of temporality to take a purely spatial form. ${ }^{2}$

Or, Out of time: as we can step out of time, such as in the expression 'he or she went out of time,' we go beyond temporality, to a place that knows no beginning or end, that is to say, to eternity. In this sense time marks our coming-into-being and our departure from it, so that it is granted with a highly ritual character.

Or, Out of time: time is a commodity that is in demand, a thing we can run out of, and of which we don't have enough. We are short of breath, we have too much to do, we have, in this sense, run out of time.

What time is really like, within and beyond outside human cognition has nowhere been more succinctly elaborated than in Kant's apriori categories. Here time plays the part of one of those frames that are necessary in order for any object or event to become perceptible to us. Nevertheless, we still haven't resolved the question of the nature of time. Does it flow smoothly, evenly, like a stream; or does it spurt out like a violent water-fall, perhaps stopping in its tracks, turning this way and that; or is time a characteristic of the world that marks how our being affects us at its most personal?

This essay brings to the table a discussion of time along these lines: is time itself an atemporal category, or has our notion of time undergone change? Benedict Anderson's important study of nationalism, Imagined Communities, claims that the introduction of nations on the world stage carried with it a novel notion of time: instead of a temporality based on the cycles of nature, nations framed themselves in a time that is linear and homogeneous (Anderson 2006 [1983]).

As we shall see, Anderson draws on earlier writers in his conception of these two contrasting temporalities. However, the way they are mobilized in Anderson's over-arching story of the emergence of nations is not without limitations. On the one hand, the temporalities he employs deserve a fuller treatment, and their juxtaposition seems arbitrary and in want of a further elaboration. And, on the other hand, should we not ask if there is a third type of temporality missing from Anderson, a time bereft of both linearity and circularity, and which

1 See Benjamin 1992 [1940], sec. IX.

2 Bakhtin mentions how for Einstein time is regarded as a fourth dimension of space which, in novelistic discourse, settles in a three dimensional topos $(1981,84)$. 
is characteristic of a way of being marked by what Martin Heidegger, drawing on Kant, referred to as 'pure self-affection' (Heidegger 2011 [1952])?

\section{Anderson's time: cyclical, linear, personal}

In Anderson's view, nations are neither a-historical substances, a la Joseph Stalin's national entities (2015 [1913]), nor historical inventions, such as Ernest Gellner suggests (1983). Rather, nations are social products, arising at the culmination of Feudal societies and coextensive with the dissemination of print-capitalism. Crucial to our investigation here is the novel notion of time enabled by the constellation conjured by Anderson. If the agrarian society typical of Feudalism was characterised by cyclical recurrence, national communities are distinguished by their notion of simultaneity across-time. In other words, while to Feudal society events in the colonial periphery tended to be perceived as reflections of originary acts in the imperial centre, nationalisms allowed for events to take place at the same time in a series of structurally equal locations.

The alteration in temporality from cyclical recurrence under agrarian society to capitalism's transverse simultaneity is supplemented by a second change in Anderson's narrative. From the religious dynasties' perception of time as pre-figuration and fulfilment -- the murder of Isaac, say, as a prefiguration of Christ's crucifixion -- nationalisms tend to perceive themselves as unfolding in a historically linear fashion, narrating their coming-into-being in accordance with clock and calendar. This latter notion is what Anderson refers to as homogeneous, empty time, that is, a temporality that has no densities, peaks, or rifts, but rather runs smoothly without interruption or intervention.

These two temporalities, then -- on the one hand a cyclical and Messianic time marked by recurrence, prefiguration and fulfilment, and, on the other, a homogeneous and empty time that allows for simultaneous events to take place -- are juxtaposed as mutually exclusive in Anderson's narrative, and, perhaps more crucial to our concern here, as chronologically ordered. While agrarian and Feudal societies perceived the world as organised with a sense of what Friedrich Nietzsche referred to as 'eternal recurrence, ${ }^{3}$ nationalisms, with their emergence around the time of print-capitalism's modernity, find that different events can take place at the same time in different locations. What organises this world isn't the relation various colonial locations have to an imperial centre, but how a series of national centres is placed on an a-historical calendarium that runs, at least in theory, from the beginning of time to its end, smoothly enumerating years, months, days, hours and seconds. In other words, what is shared among these novel social entities is their common allegiance to this calendarium, and their willingness to organise their stories about themselves around this temporal emptiness.

Now, when we look a bit deeper into the sources for Anderson's conceptual apparatus, we notice that while the chronology is a novelty imposed with the publication of Imagined Communities in 1983, the term Messianic time is, as Anderson duly acknowledges, a term drawn from Walter Benjamin's 'Theses on the Philosophy of History'. Here, Benjamin suggested that we live in a time characterized by disastrous events, and that our only hope for

3 'Let us think this thought in its most terrible form: existence as it is, without meaning or aim, yet recurring inevitably without any finale of nothingness: "the eternal recurrence"'(Nietzsche 2015 [1888]). 
redemption is some kind of Messianic event that will release humanity and usher into a new kind of community. In his conclusion to the essay, Benjamin wrote:

We know that the Jews were prohibited from investigating the future. The Torah and the prayers instruct them in remembrance, however. This stripped the future of its magic, to which all those succumb who turn to the soothsayers for enlightenment. This does not imply, however, that for the Jews the future turned into homogeneous, empty time. For every second of time was the strait gate through which Messiah might enter. (Benjamin 1992 [1940], sec. XVIII)

To Benjamin the juxtaposition of homogeneous, empty time with Messianic time was not a device to show how a certain social constellation abandons and overthrows a previous notion of temporality. Rather, it was an attempt to show a distinguishing mark of true historiography as opposed to mere historicism.

A season to sow and a season to reap the harvest, a cycle of repetition and return, a foretelling and its actualisation -- all these senses are captured by the term Messianic time. ${ }^{4}$ When the dominance of religious institutions and the prevalence of agrarian subsistence typical of Feudal society were replaced by the modern nation-state, a novel notion of time accompanies this new sense of community. We remember that Benedict Anderson, following Walter Benjamin, refers to this notion as homogeneous and empty, in the sense that is has no ruptures, fissures, peaks or lacunas. It flows in a steady, linear stream, and it enables its adherents to imagine several events to take place at the same time, in different locations.

What is crucial here is to note the direct parallel to the temporality envisioned by Guy Debord in his seminal Society of the Spectacle, a notion of time that he associated with the rise of commodity society:

The irreversible time of production is first of all the measure of commodities. Therefore the time officially affirmed over the entire expanse of the globe as the general time of society refers only to the specialized interests which constitute it and is no more than a particular time. ${ }^{5}$

Debord, in a nod to Novalis, acknowledged that the journal, the chronicle, and the archive enshrine 'irreversible time' as the time of those who rule. ${ }^{6}$ However, Debord took the view that nations are part of a 'voluntary progression' (ibid., §132), and that makes him a distant relative of Ernest Renan, who held that nations are not organic entities rising from the soil of the land, ${ }^{7}$ but voluntaristic communities in need of daily plebiscites to affirm their continued existence (1990 [1882]). In Debord's account, voluntarist, irreversible -- and, we may add, homogeneous and empty -- time, is an invention of the owners of history who 'have given

4 Guy Debord pointed out that 'cyclical time already dominates the experience of nomadic populations because they find the same conditions repeated at every moment of their journey: Hegel notes that "the wandering of nomads is only formal because it is limited to uniform spaces"' (1983 [1967], §127).

5 Ibid., §146, emphasis in the original.

6 Debord quotes from Novalis that 'writings are the thoughts of the State; archives are its memory,' ibid., §131 132.

7 Heidegger held that Being (Dasein) has a "mission [that] opens and binds Blood and Soil [Blut und Boden] to a readiness for action and a capacity for realization and work" (quoted in Gordon 2014). 
time a meaning.' Here, history becomes the 'private property' of those who govern: 'under the protection of myth' they take control over time as a 'mode of illusion' (1983 [1967], §132).

As we can see, the entanglement of a declining religious and Feudal world order with the emergence of a novel technology of dissemination embedded in a mode of production, which Anderson refers to as 'print-capitalism', lends itself to a reading of national temporality as an instance of what Guy Debord called irreversible time: it is a specialized time, born of the interests of an emerging class of owners and rulers, disseminated by means of a new technology of governance -- the nation-state -- and, finally, entrenched on a global scale with the immutable imposition of a particular way of living in the world. It is a precondition for a world market, in which a vast majority voluntarily answers to the address of consumption.

Nevertheless, already Kant acknowledged that time isn't really reducible either to the cyclical recurrence of agrarian life, or to some kind of linear calendarium. In the Critique of Pure Reason, he identifies time as 'nothing but the form of our inner sense, which is to say [...] the perception we have of ourselves and our inner condition.' Already to Kant, then, there isn't any objective time: temporality is an experience -- a perception -- we have, and it is this formulation that later led Martin Heidegger to regard time as 'pure self-affection:' time is not an affect that encounters an already existing self, but 'in its pure form the essence of concerning-itself (sich-selbst-Angehen). ${ }^{18}$

To step out of the homogeneous, empty time of the calendarium is already to enter into the kind of temporality indicated by Kant and Heidegger. Here the self is, in the words of Heidegger, 'enabled to be what it must be: referred to reception.' Again, Heidegger puts Kant's temporality to use in a notion of prefiguration: the task of the self is to receive what is already present as essence. When this notion of time appears as a form of psychological time, it is not only because it avoids inscription into a world historical order, but also due to its entanglement with memory. ${ }^{9}$

To fully grasp the position Heidegger takes on temporality, we need to understand what he means by the term thinking. To Heidegger, this term should be used to mean more than simply rational problem-solving. Thinking is, rather, something we are called to do, and it is this calling -- or, if you wish, this addressing -- that causes us to pause and reflect. Heidegger continues,

What calls on us to think demands for itself that it be tended, cared for, husbanded in its own essential being, by thought. What calls on us to think gives us food for thought. (2011 [1952], 276-277)

8 Martin Heidegger, Kant und das Problem der Metaphysik, Frankfurt am Main: Vittorio Klostermann, 1991, p.189; quoted in Braastad Myklebust 2011, 97, author's translation.

9 It is worth noting how the psychoanalyst and student of Heidegger, Jacques Lacan, would claim the difference between narcissism and this kind of self-affection. While the former is characteristic of an imaginary order that postulates a dualistic relation between the self and his or her image -- the self identifies with the image -- the latter presupposes an intervening third element, what Lacan referred to as the Big Other. When the subject exits the spectral phase of the Mirror Stage, it is able to grasp that all desire is mediatized, and that this mediatization takes place on the ground of this Big Other. It is a social I: beyond the fortress of the ego it realizes the temporary and fluctuating character of all identities. See Lacan 1977. 
It is this caring for, holding or, as he puts it elsewhere, protecting, that is the gift of thought (ibid., 261). It is in this gifted state, then, that we are capable of thinking, and it is here that time can become pure self-affection, a mere fourth dimension of space.

It is, in a sense, timely that Heidegger's personal writing -- his Black Notebooks -- has become the topic of much public debate now that the post-Cold War détente is reaching its end. ${ }^{10} \mathrm{We}$ live in a time with renewed questioning of issues such as human rights, the role of the state and a troubling re-emerging arms race. When we know Heidegger's position in establishing the disastrous regime of the 1930s Germany, it is worth listening to his opponent in things ideological, Walter Benjamin, when we end by asking how can we find a place for the thought of Heidegger -- which Benedict Anderson didn't -- in a way that doesn't deny his involvement in the Third Reich?

In a fragment written in 1921, which remained unpublished in his lifetime, Benjamin draws a distinction between the legal and the moral universe. While the former is marked by retribution, the latter is enveloped by forgiveness. The moral universe, Benjamin writes,

struggle[s] against retribution [and in this] finds its powerful ally in time. For time [is] the tempestuous storm of forgiveness which precedes the onrush of the Last Judgement. This storm is [...] the hand that obliterates the traces of his misdeeds, even if it must lay waste to the world in the process. (1996 [1921], 286-287)

This is a time beyond recurrence and calendar, but possibly not beyond Messianic time. As with Benjamin's thought-image ${ }^{11}$ of the angel of history, who is pulled, against his will, by a storm emerging from the future into a completely novel time-space constellation (Benjamin 1992 [1940], sec. IX), the tempestuous storm of forgiveness that precedes the Last Judgement makes it possible to forget the misdeeds that have caused pain and suffering.

In this precise sense, Benjamin's Messianic time offers a way for us to readmit Heidegger's thinking: it is a way for a future promise to suspend our traumatic remembering.

As Benjamin closes his argument on the moral universe: 'Time not only extinguishes the traces of all misdeeds but also -- by virtue of its duration, beyond all remembering or forgetting -- helps, in ways that are wholly mysterious, to complete the process of forgiveness, though never of reconciliation' (1996 [1921], 287).

\section{Mind time: logical time and time of trauma}

When we recount these three notions of time -- a time that allows the subject to maintain an

10 With regards to Heidegger's position in our current intellectual climate, it is worth noting the remarks Alain Badiou made with reference to the notion of the new man. To Badiou, there are two distinct conceptions of this emergent social figure. On the one hand, we have the new man of restoration: a person who sheds the false, the deceptive and the inauthentic, and in turn reestablishes man as he was at some mythical origin. On the other hand, there is a new man that is truly novel: this person is new because she or he has no precursor. This man figures as a possibility for what Giorgio Agamben has referred to as the coming community: a personage that holds the power to establish a new kind of singular universality (Badiou 2002). For an introduction to the debate on The Black Notebooks see Gordon 2014.

11 The notion of Denk-bild as a device in the work of Benjamin is brought into play in Weigel 1996. 
organic relation to his Umwelt typical of agrarian society, an objective time marked by clock and calendar, and what we have so far referred to as psychological time, or a time of pure selfaffection -- we realize that what they have in common is that there nonetheless is temporality: there is change in us, and the world changes with us.

Whenever we bring up the history of psychoanalysis we should be aware of the complexity time played from the very beginning of Freud's mental topology. In his view, the ego came into being as an effect of the id, and to Freud the ego was an instrument precisely to master the drive. In one formulation, he claims that the id as a hereditary mechanism that contains within itself 'the existences of countless egos' (Bowie 1991, 17). It is this notion of the ego as a core of a mental spatiality that becomes the central piece of psychoanalytic questioning. Already Freud took issue with classical psychology's view of the self as unified and unitary. Instead he found the ego to be most distinctly articulated in riddles and hypotheses. In the end, his idea of the ego who self-assuredly defeats the id is exempted from the field of observation. It remains rather as 'a wish, a hope, a recommendation' (ibid., 21).

If the id is a corollary of 'countless egos' in Freud's topology, it is indicative of the spatial logic of psychoanalytic thinking. The id doesn't really have a temporal existence: it manifests itself in the drive, and as such it is eternal. The same holds for the ego, since it is an atemporal residue of the id. The task of psychoanalysis, as Freud saw it, was to 'enable the ego to achieve a progressive conquest of the id. ${ }^{12}$ When Freud surrendered the ego to the overpowering force of the drive, he prepared the ground for a move made with great bravura in the early writing of his French inheritor, Jacques Lacan. To Lacan, the ego is not the final stage in the development of the subject, but merely a 'stage,' or, to reduce the importance of the ego even further, a phase in a stage -- the Mirror Stage.

It is here that temporality returns with force to psychoanalytic thinking. There is time in the mental chart of Lacanian psychoanalysis, even if this temporality is neither cyclical nor characterized by the objectifying measures of clock and calendar. With Lacan, the a-temporal notion of the subject is brought to an end: the ego has a history, and it is a history of trauma.

While Lacan's first intervention in the Freudian field of psychoanalysis was to draw attention to a temporality that was underplayed in Freud's topological metaphor of the psyche, this notion of time is clearly distinct from the time of historicism. To Freud the unconscious had a geography: it was marked by spatial locators. In the work of Lacan the unconscious is not so much a site of unacknowledged and unknown processes as it is a flow. In Lacan's famous formulation, the unconscious is a discourse, and it is the discourse of the Other (2006a, 10). Implicit in the emphasis on discursive articulation embedded in Lacan's psychoanalysis is a new interest in the temporality of the unconscious, even if it is a time that is personal, subjective and even troubling.

To grasp how Lacan foregrounded the traumatic kernel of our being in a temporality of subjectivity it is necessary to understand how the Lacanian subject is always brought into being in a relation to an order of desire. Our entry into the symbolic order is marked by a refusal on the father's part: we are denied access to our most cherished object of affection. It is as a result of this intervention that our desire is made into an object of the law. In fact, we

12 Sigmund Freud, Collected Works, vol. XIX, p. 56; quoted in Bowie 1991, 20. 
become subjects by this very token: by refusing access to the Oedipal love object, we gain access to a world of desire. It is as if the father is speaking: 'this is your mother, there are many women, as far as your father is concerned you may have any one of them, but there is a limit, and that is my wife, your mother, she is mine.'

It is this trauma, what Lacan referred to as the Father's no (the non du père), that enables the possibility of desire. Through this intervention we become aware of that there is a lack, and it is our attempt to contain the sense we have of something absent that compel us to attain a love object. Our entry into the realm of desire is therefore marked by an impossibility: as we are subsumed within the law of desire we are denied access to the very object we seek to appropriate. The inevitable failure we experience throws us into a drama marked by what Lacan called primordial jealousy. We need to come to terms with a situation in which our preferred love object is unattainable. The way this is resolved is by transference: we shift our desire onto some object or person that is within the boundary of the law. This shift is metonymical in character: our new love object is a partial replacement of our primary -- even if unattainable -- object of desire.

The instance from where the law is articulated is what Lacan referred to as the Big Other. It is this instance that regulates our desire, and it is at the moment when we submit to the Other that we become properly speaking subjects. To understand our relation to this instance, we are continually deferred to a position of questioning: what is it that the Other wants from us? It is as if we are caught in one of those riddles of the unconscious: I can't tell you exactly what or who you are, but in time the answer will become clear to you.

To show how time of the unconscious works, Lacan made use of what he called a sophism (2006b, 161-175). In this thought experiment a prison warden is due to release one prisoner. He has picked three candidates, and in order to find out which one of them is best fit to be released he puts them to a test. They are to be placed in a room with a disk fitted to their forehead in such a way that they cannot see the colour of their own disk, but only those of the other two prisoners. They are told that there are three white and two black disks to be distributed. When a prisoner has figured out his own colour, he can freely leave the room and tell the warden how he found the solution. The first prisoner to leave the room and provide the right explanation will be released.

Before fitting the disks to the prisoners, the warden discards the two black disks. After having considered the situation for a while the prisoners leave the room together, side by side. They all provide the same explanation to the warden, which is as follows: 'I am white, and this is how I know it. My fellow prisoners were white. If I was black, each of them could have made the following inference: if I'm also black the other [third] prisoner would have left the room immediately, having seen two black disks. Therefore I'm not black. And both would have left the room together, knowing they were white. Since they did not do this, I must be white like them. When I had drawn this conclusion, I headed for the door to make this announcement.'

The question in this game is 'what is my colour.' Each prisoner has been assigned a colour by the warden, and they don't immediately know which one it is. Only time, or, more precisely, the other prisoners' hesitation enables each prisoner to figure out his own disk. The key point is not only that each prisoner need put himself in another prisoner's situation, but that it is necessary for him to see himself from the perspective of another. In Lacan's sophism this is 
not an easy matter, since the riddle can only be solved by incorporating into itself the acts of others.

Time receives an urgency beyond the linearity of historicism in this experiment: if anyone leaves the room immediately it is because he sees two black disks, and draws the conclusion that he himself is white. If some time passes before anyone leaves, it would mean that two prisoners see one black disk and assume that the other's hesitation indicates that there are not two black disks in circulation. If none of these criteria has been satisfied, some more time will pass and the prisoners will leave the room together, convinced that only white disks have been distributed.

It is as if the more time that passes, the closer the prisoners get to the recognition of their own destiny. The prisoners can only rely on their own ability to draw logical conclusions based on changes in actual relations (or, in this case, a lack of change in relations). This is how we are brought into being by the instance called the Big Other: the power lines of history, the desire of our ancestors, the dice that was thrown in precisely the way it was cast -- there were background vehicles that made the constellation we are at any time situated within. It is not a question of subjective choice, and yet it is something we must make our own. ${ }^{13}$ Our destiny is something we subjectivise.

This is the meaning behind Freud's dictum wo es war soll Ich weren -- where it was shall I become. Where foreign powers -- language as a system of symbolism, our parents' desire, etc. -- dominated, I shall become the subjective champion of what is alien.

\section{Legal time and time of grace}

The question of volition in relation to faith has a long history in religious thought. In his introduction to Blaise Pascal's Thoughts, T.S. Elliot remarks that a chief line of demarcation between the Jansenists, to whom Pascal were aligned, and the dominant Jesuits were drawn precisely with regard to the place each camp assigned to the notion of free will (2006 [1958]). This debate was staged around the notion of grace: the Jansenists thought that the doctrine of a grace that was sufficient would not be able to account for God's presence in the world. The Jesuits held that the grace conferred upon mankind is subordinated to volition. It is effective without any additional assistance, and is therefore sufficient (Agamben 2011, 260-261). The Jansenists would claim that there is no grace that is sufficient unless it is also effective. A principle for action that does not determine the will to act effectively would be insufficient. Since only God can act with effective grace volition is subordinate to grace.

The distinction between the Jansenists, who were arguing for their place within the official doctrine, and the Calvinists, who had been condemned as heretics was made by reference to determinism. While the Calvinists perceived man as so degraded through Original Sin that the will would be of no benefit -- and that our destiny in the coming world was already determined prior to our acts -- Pascal relied on the theory of Grace as it had been formulated by Augustine. In this view Christ died for all, and the grace bestowed as a consequence is irresistible.

13 Heidegger notes that our horizon amounts to 'something like a region, an enchanted region where everything belonging there returns to that in which it rests.' (2010 [1959], 65). 
When the Jansenists were later condemned as heretics the doctrines of sufficient grace and free will were enshrined without significant opposition as official dogma. This assignation of the view of God's grace as determinate of acts meant that grace was removed from the strictly legal domain. Pascal was mindful of this distinction when he noted that

The law has not destroyed nature, but has instructed it; grace has not destroyed the law, but has made it act. Faith received at baptism is the source of the whole life of Christians and of the converted. $(2006, \S 519)$

Grace is the agent that animates the law in Pascal's view. The assumption is that a clear distinction can be made between the legal realm and the domain of faith, and that the autonomy granted to human legislation acts upon nature in a way that is analogous to the way grace acts by way of the law. The key component to Pascal's perception of the interrelation between human society and the domain of grace is found in the intervention of ritual: through a moment of passing humans enter into a relation to faith, which again serves as the basis for both the law and the reception of grace. In psychoanalytic terms it is the imaginary residue of the thou art that of spectral identification that both the legal and the spiritual community comes into being, and it is the specificity of the faith inaugurated by the ritual moment that serves to determine the relation between man and his world.

Pascal is very clear that it is by God's willing that we receive grace. It is not within the human domain, and therefore it would unreasonable to expect from oneself to grant grace. Instead, it is in 'expecting nothing from yourselves, that you must hope for it' (ibid.: §516). In other words, grace is an external agent that acts upon the human community. This is why it is contradictory to demand grace from law. Law is a human pursuit and grace is works as an independent, external agent.

Pascal asserts that there are two distinct ways to bring the Other into worldly existence: through reason and through emotion, and both of these ways are necessary for the Other to act. The impasse reached with regard to the doctrine of sufficient grace belongs to the domain of propositional logic. If a moment sufficiently explains an event, then it is entailed that there is some other necessary cause that is unarticulated. In this sense, a sufficient reason that is not necessary is inefficient, or, in the words of Pascal, it is insufficient, since a determinant of action must be necessary to have efficacy. What we are faced with is a split between doctrine and reason: on the one hand, the dogma holding that there was no necessity for efficacious grace, and, on the other, the demands of reason, which finds a contradiction in terms between faith and the claim that there would be some domain that was exempt from the governance of grace.

The difference between the world of law and the domain of grace lies in the relation between its subject and the kinds of demand that is entailed. Pascal notes that 'the law imposed what it did not give. Grace gives what is imposes' (ibid., §521). There is no charity embedded in a legal relation. The imposition brought about by a legal injunction has no sense of a gift, while the imposition of grace implies the opposite relation.

This is why it the distinction between the legal and the moral universe is derived from the difference in these domains to the notion of retribution. As Benjamin points out retribution is 
indifferent to the passage of time. In some 'heathen conception' even the Last Judgement 'is regarded as the date when all postponements are ended and all retribution is allowed free rein' (1996 [1921], 286). What is clear is that compensation and reparation tends to be governed by some temporal statute of limitation in common law. Nevertheless, some particularly vile crimes, such as murder, does not necessarily confine the retributive act in such a way. In older forms of law retribution could span generations, and it is these kinds of destructive acts of revenge by tribes visited upon tribes that is the topic of many of the Old Norse sagas (Shippey 2015, 23).

Time has a different character in the moral universe. It is no longer compensation and revenge that holds the centre stage. Rather, it is a universe where the gift and forgiveness comes to the fore.

\section{The later Anderson: post-nationalism and time's beyond}

If the time of the nation in Benedict Anderson's Imagined Communities heralded a shift from cyclical recurrence to the linearity of clock and calendar, it was also indicative of a time of consumption regulated by sovereign jurisdiction. Retribution and recompensation demands a common temporal denominator, and the calendar is there not only to indicate the limit beyond which it is no longer permissible to pursue a path of reprisal, but also to track the time when compensation has been meted out.

Benjamin's moral universe is founded on a temporality that undercuts any such notions of linearity and measurement across time. While forgiveness, the moral attribute par excellence, is beyond the domain of human sensibility, it works on its own while a mysterious tempest is raging in the legal landscape. This storm, imbued with the capacity to wipe our not only the wrongdoing, but also the wrong-doer and his victims, causes us to forget the crime. This is our task, then: to forget the vicious act and its perpetrator, while the powers of nature -Spinoza's divine authority -- completes the task of forgiveness.

It is in this precise sense that Benjamin's moral time marks a temporality that is beyond clock and calendar. During the raging tempest we simply forget to keep track of violations and retributions and we arrive on the other side with no memory of the wound that had been inflicted on us. Here Benjamin's temporality shares some significant features with the time Heidegger referred to as a time that is purely of concern to our selves. Beyond the scope of utility and calculative reasoning this is a temporality that is deeply concerned with the subjective experience of the existence. It is indicative of the other kind of thinking, where we, so to speak, remember to forget.

In Anderson's narrative in Imagined Communities, the nationalist story emerged in Latin America with the decline of imperial and Feudal governance and the advent of printcapitalism; it continued when established states realized that nationalism was a tool that could be used to entrench their hold on the citizenry, and it culminated with the development of linguistic nationalism. This third wave of national conception had as its philosophical origin the theories of Herder and Rousseau, asserting that each nation was signified by a separate language and culture, which expressed the nation's 'historical genius' (Anderson 2001, 40). This movement ushered in dictionaries for national languages and the writing-down of oral literary traditions in Greece, Germany, Norway, and, later, Bangladesh. 
In his later writing Anderson shows how globalization has served to undermine the distinct shift in temporality inaugurated by nationalisms. With television, new information technologies, massive migrations of populations and so on, languages no longer hold the capacity to define the singular sense of belonging that it did during the productive phase of nationalist imaginings.

This is why the appeal of linguistic nationalism is waning: when information technologies make it possible to use different languages in various contexts, an entirely new form of nationalism appears. With the reduced importance of spatial distinction the territorial location of the nationalist subject is no longer essential.

The internet, electronic banking and cheap international travel [allow] people to have a powerful influence on the politics of their country of origin, even if they have no intention any longer of living there. (Ibid., 42)

This kind of long-distance nationalism could have a largely symbolic significance, where the diasporic subject at times performs his nationalism-of-origin, and at others that of his nationof-residence.

Anderson's later work on national diasporas shows that nations no longer occupy the same differential positions in a serial sequence that was assumed at the inaugural moment of nationalism. What is crucial here is that when nations are no longer a geographical necessity linking the soil to those that inhabit it, the law resides in some other instance than the national. It isn't any longer the case that a national sovereignty can be defined as a selfregulating territory, beyond which there are other self-regulating territories. The domain of the law has moved from a simple geographical attribution to a complex, post-national stage, where every square centimetre of the globe is dominated by law.

By sifting through the historically sedimented forms of governance we arrive at the juncture where Heidegger meets Benjamin: what is called for is a releasement [Gelassenheit], which to Heidegger meant not only the common notion of letting go of obsolete conceptions, but also the idea that we are ushered into a new domain. To Benjamin this act was indicated by a strong wind, 'blowing from Paradise,' which enables us to forget our wounds and open up for the possibilities of the new. In the work of Heidegger the movement into the field of thought characteristic of the calling of thinking:

Releasement comes out of that-which-regions because in releasement man stays released to that-which-regions and, indeed, through this itself. He is released to it in his being, insofar as he originally belongs to it. He belongs to it insofar as he is appropriated initially to that-which-regions and, indeed, through this itself. (2011 [1952], 73)

Thinking, and, by extension, releasement, is crucially about locating for oneself what has been present all along, namely our destiny. This is the future site from where the tempest rages to eradicate all traces of past wrong-doing, and it is this land of tomorrow that enables us to continue thinking and examining our existence. 
The time that is called for and which, in turn, calls for us is a time not of remembering, but of forgetting. When we find what we have been looking for, Heidegger writes, we do well to turn away from it. ${ }^{14}$ This is why Benjamin's angel of history has his gaze turned away from the future, the site from whence the wind blows and the agent of the debris that piles up before our eyes. By turning away, we shield our future belonging and praise its power.

The question of destiny has been central to psychoanalytic thinking, and to Lacan it evoked the quest in such disparate cultural domains as Chinese divinatory practice and ancient Greek philosophy. In the former, the seer places shells of a tortoise on a fire and reads the cracks that are formed in the shells as signs of the future. In the latter, the lightning of Heraclitus makes the slow mutations of Being surge forth in the night (Laurent 2007, 27). In order to be found by our destiny, Lacan asks if it is

your figure that traces our destiny for us in the tortoise-shell cracked by the fire, or your lightning that causes the slow shift in the axis of being to surge up from an unnameable night into the [Daimon] of language? (2006c, 420; cf. n504,1, 808) ${ }^{15}$

It is the power of the One to name things, and it is through this power that we are called to find our path forward. As Lacan noted when discussing Chinese poets and their timeconceptions, it is the task of the translator to transform the ruptures of our past into an active thought, 'linking for you your present with your past - [then] you will, at last, be in your time. $^{.16}$

\section{References}

Agamben, G. (2011) The Kingdom and the Glory, trans. L. Chiesa (with M. Mandarini), Stanford, California: Stanford University Press

Anderson, B. (2006 [1983]) Imagined Communities, London: Verso

---. (2001) 'Western nationalism and Eastern nationalism: is there a difference that matters?', New Left Review, 9, May-June, 31-42

Badiou, A. (2002) 'One divides into two', trans. A. Toscano, Culture Machine, vol. 4, [online]. Available at http://culturemachine.net/index.php/cm/article/view/270/255. Accessed 30 June 2015.

---. (2006) 'Lacan and the Pre-Socratics', [online]. Available at http://www.lacan.com/badpre.htm. Accessed 15 September 2015.

\footnotetext{
14 'If thinking is what distinguishes man's nature, then surely the essence of this nature, namely the nature of thinking, can be seen only by looking away from thinking' (ibid., 57).

15 The Greek term is from Heraclitus, and translates as logos or deity, cf. Badiou 2006.

16 Lacan in conversation with the poet François Cheng, quoted in Laurent 2007, 50.
} 
Bakhtin, M. M. (1981) The Dialogic Imagination, ed. M. Holquist, trans. C. Emerson and M. Holquist, Austin: University of Texas Press

Benjamin, W. (1992 [1940]) 'Theses on the philosophy of history' ['On the concept of history'], in H. Arendt (ed), Illuminations, trans. H. Zohn, London: Fontana, pp. 245-255, [online]. Available at http://www.tasc.ac.uk/depart/media/staff/ls/LNSindex.html. Accessed 13 February 2015.

--- (1996 [1921]) 'The meaning of time in the moral universe', in M. Bullock and M. W. Jennings (eds), Selected Writings: 1913-1926, vol. 1, trans. R. Livingstone, Cambridge, Massachusetts: Harvard University Press, pp. 286-287

Bowie, M. (1991) Lacan. Cambridge, Massachusetts: Harvard University Press

Braastad Myklebust, R. (2011) 'Språk, subjektivitet og livspolitikk. Om et grunnproblem i Giorgio Agambens filosofi', Agora, vol. 29, no. 4, 74-102

Debord, G. (1983 [1967]) Society of the Spectacle, Detroit: Red \& Black

Elliot, T.S. (2006 [1958]) Introduction. Pascal's Thoughts.

Gellner, E. (1983) Nations and Nationalism, New York: Cornell University Press

Gordon, P.E. (2014) 'Heidegger in Black', The New York Review of Books, [online], 9 October. Available at

http://www.nybooks.com/articles/archives/2014/oct/09/heidegger-in-black/.

Accessed 30 June 2015.

Heidegger, M. (2010 [1959]) Discourse on Thinking, trans. J.M. Anderson and E.H. Freund, New York: Harper \& Row, published by The Internet Archive/University of Florida, [online]. Available from http://www.archive.org/details/discourseonthinkOOheid. Accessed 14 August 2015.

---. (2011 [1952]) 'What calls for thinking?' in D.F. Krell (ed), Basic Writings, London: Routledge, pp. 261-277

Lacan, J. (1977) 'The mirror stage as formative of the function of the I', in A. Sheridan (ed and trans.), Écrits - A selection, New York: Norton, pp. 1-7

---. (2006a) 'Seminar on "The Purloined Letter"', in B. Fink (ed and trans.), Écrits. New York: Norton, pp. 6-48

---. (2006b) 'Logical time and the assertion of anticipated certainty', in Écrits, pp. 161175

---. (2006c) 'The instance of the letter in the unconscious, or reason since Freud', in Écrits, pp. 412-441 
Laurent, E. (2007) 'The purloined letter and the tao of the psychoanalyst', in V. Voruz and B. Wolf (eds), The Later Lacan, New York: State University of New York Press, pp. 25-52

Nietzsche, F. (2015 [1888]) The Will to Power, [online]. Available from https://archive.org/stream/TheWillToPower-Nietzsche/will_to_powernietzsche_djvu.txt. Accessed 30 June 2015.

Pascal, B. (2006 [1958]) Thoughts, New York: E. P. Dutton \& Co., Inc, Gutenberg eBook \#18269, [online], April 27. Available from http://www.gutenberg.org/files/18269/18269-0.txt. Accessed 14 March 2015.

Renan, E. (1990 [1882]) 'What is a nation?' in H.K. Bhabha (ed), Nation and Narration, New York: Routledge, pp. 8-22

Shippey, T. (2015) 'Troll-headed bruisers', review of W.I. Miller, '"Why is your axe bloody?": a reading of Njal's Saga,' The London Review of Books, vol. 37, no. 13, July 2, pp. 23-24

Stalin, J. (2015 [1913]) 'Marxism and the national question', [online]. Available from http://www.marxists.org/reference/archive/stalin/works/1913/03a.htm. Accessed 30 June 2015.

Weigel, S. (1996) Body- and Image-Space: Re-reading Walter Benjamin, trans. Georgina Paul, London: Routledge

Torgeir Fjeld is based at the University of Gdansk.

Email: torgeir_fjeld@yahoo.no 